\title{
Geomorphologic Research in the Velika Ukrina
}

Tosic, R.*

Abstract In the article the problem of genesis and morphological evolution of the relief of basin of Velika Ukrina will be examined. Basin of Velika Ukrina includes the area of south brim of Panonnian basin, which is relatively being a little bit extracted, therefore, understanding of the series line of geomorphologic phenomenon and processes in this part of this basin is very significant. The results of research beside scientific have on first place practical importance, especially when we speak about problem of water supply as well as problem of the erosion.

Key words Morphology, morphogenesis, geomorphologic analysis, tectonical activity $\longrightarrow$ eomorphological research of the relief of basin of Velika Ukrina have had as basic aim solving the problem of genesis and morphological evolution of the relief in global, but also specific shapes of the relief of this basin. The central problem, used to form the released solution of morphogenesis of the relief is its elbow-deviation. Problem of elbow-deviation of river valley of Velika Ukrina has pointed to the need of researching of the cause, respectively the reason of the change of direction, but also to the need to find the answer to the question of former extending of river valley of Velika Ukrina. Answer to this question isn't only the explanation of the problem of morphogenesis of the relief of basin, respectively the explanation of genesis of particular shapes of relief which are today being recognized in the basin, but with it, it was the aim to point out to some gemorphological processes, which have had and nowadays have significant influence in shaping the relief of the basin.
Velika Ukrina river is the left constituent of the Ukrina river, placed in north part of Republic of Srpska, respectively in western part of northern Republic of Srpska, among mountains Uzlomac, Borje, Ljubica, Javorove and Cavke. With its geographic condition it is the part of Internal Dinaridi, respectively Dinara region that clearly represents geotectonic whole. The complexity of geological composition, tectonical characteristics, as well as all other physical - geographic conditions, has reflected to morphostructural and morphosculptural characteristics of this whole.

The surface of the basin is $315,97 \mathrm{~km}^{2}$ and the length of river course is 45,250 $\mathrm{km}$. Total fail of Velika Ukrina is 490 $\mathrm{m}$, while the value of average fail is $10,828 \%$. The density of the river network defined according to the Nojman form is 2,16. Beside these morphometric data, and with the aim to understand the process of building the basin as morphological category, it is important to stress that the value of flowing is $1,554 \mathrm{~m}^{3} / \mathrm{s}$ and the values of specific swelling is $4,92 \mathrm{l} / \mathrm{sec} / \mathrm{km}^{2}$.

\section{Geological Composition and Tectonical Circumstances}

Basin of Velika Ukrina has complexed geological - tectonic structure, built by layers of different stratigraphic members of Mesozoic as well as Cenozoic age. However, in the basin there are no surface manifestations of the cliffs of Paleozoic age.
* Radislav Tošić, Faculty of Natural Sciences, Banja Luka, M.Stojanovića 2. 78000 Banja Luka, Bosnia and Herzegovina

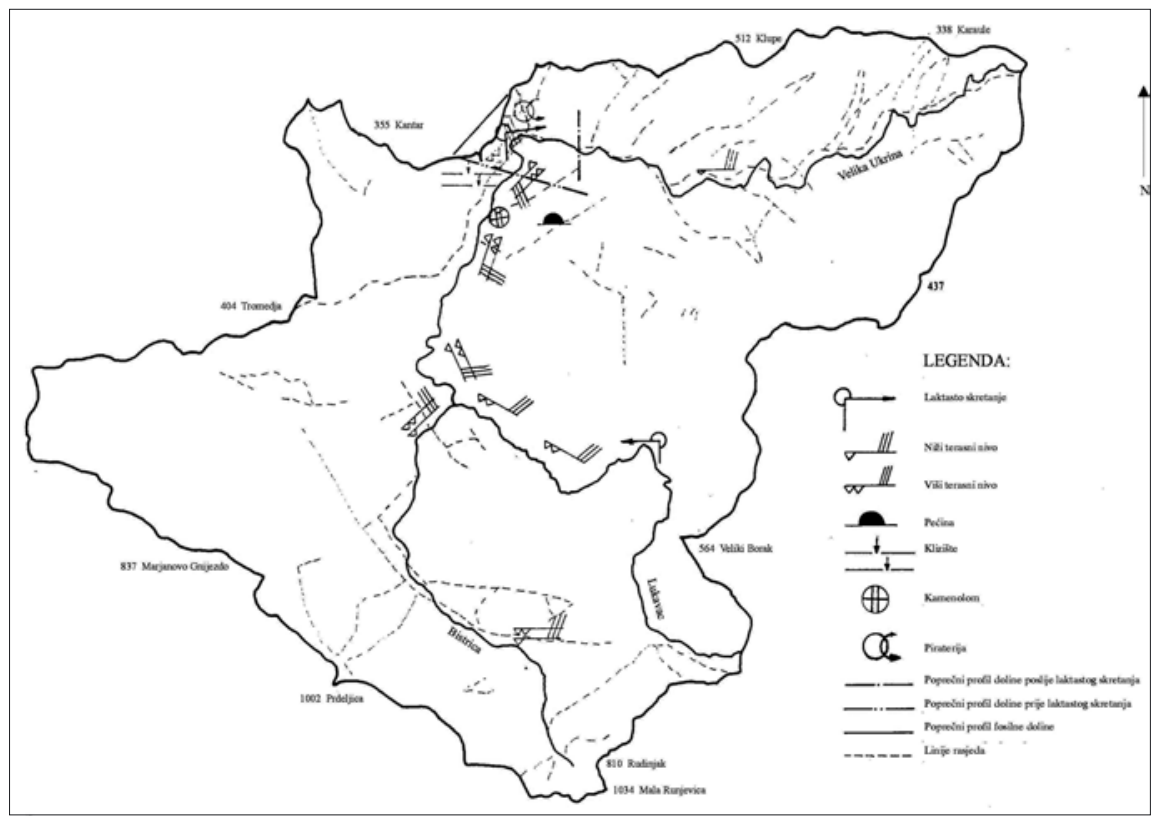


Trias - jure complex has significant role in the structure of southwest part of the basin. This complex was built of lime-stone sediments with participation of sandy, clay and clastic products while in ofiolit zone there are sedimental - volcano products. Sedimental rocks of dijabaz - horny formation are presented as indivisible complex, in particular places of litological homogenical structure, shows up as breča or horn, somewhere with lime-stone and metamorphic rocks. We connect these formations to the lower part of flow of Velika Ukrina river, respectively for left and right valley side from the village Gornji Vijacani all the way to the conjunction with Mala Ukrina. The same rocks complex extends also on the right side of Lukavac river, trough villages Gornja Snjegotina and Parlozi, where the significant spreading is present, but also from the both valley sides of Bistrica river (Sofilj, et.al.,1983). Peridotit amfibolitske and spilit - ceratofir - dijabaz - doleritsko - gabro - granit association of dijabaz - horny formation, as significant unit of ofiolit zone, build unique entirety of typological metamorphic complex on which on the rare undamaged profiles of contact area we notice concordat mutual layering. Peridotits in percentage as most present rocks of ofiolit complex in the area of basin of Velika Ukrina, are placed in the bottom of south brim of Ljubic mountain, at the end of northwest of basin in the basins of constituents of Velika Ukrina, basin of Kamenica and Jelovac, but also on the separated massive of Snjegotina with the surface of 40 - 50 km² ( Sofilj, et al., 1983). Magma sedimental complex, known as dijabaz - horny formation, represents the most important geological unit of ofiolit zone, which in the basin of Velika Ukrina has significant expand. The biggest part of ultramafit rocks is related to Borja mountain, while the amphibolites, dolerites, dijabaz and gabri are remarkably rare stratigraphic members.

Cenozoic of the basin of Velika Ukrina, are built by sediments of terciar as well as sediments of kvartar. Paleocene and Eocene sediments, which in their litological structure consist lapor limestones have small surface of expand in the village Gornji Vijacani and on the left valley side of Velika Ukrina. Neogen products in the basin of Velika Ukrina are related to layers of Miocene and Pliocene, and show up like isolated parties in the area of Velika and Srednja Snjegotina, Stara Dubrava, Parlozima, Savicima, but also partially in peridotic association of the rocks in the area of the basin of Loncarice river and in dijabaz - horny formation of sandy, clay, horny, with small parts of dijabaz and spilit in the area of the basin of Borovica river (Sofilj, et al.,1983).

Kvartar layers take relatively huge surface, comparing to the layers of other stratigraphic units, represented with river terraces as well as with alluvia which became on the place of rapidly change of the course of river flow.

According to geotectonic rejonization of Dinaridi (K.Petkovica, 1961), the basin of Velika Ukrina belongs to geotectonic units of Internal Dinaridi and Central ofiolit zone. On the north the boundary line to ofiolit zone represents dislocational direction Kozara - Klasnice - Turjanica - Cavka, extend direction northwest - southeast, marked as rupture of regional significance, and on the south expressive saging direction Okolica - Kremna - Dragalovci and Jelah.

Tectonic structures or structural facial units that are being extracted in the basin are the most emphasized lines of the relief, but at the same time they are the basic on which the other relief shapes have been developed. Analyzing tectonic units, it is possible $t$ conclude about the relation between particular shapes and elements of the relief in the basin, and if the basin is observed in its widest boundaries and if the micro forms are extracted, then tectonic units are expanded as huge forms, which help in explaining of the development and genesis of the basin (Andjelkovic, 1980).

\section{Morphology of the Valley of Velika Ukrina}

In genetic and morphologic view, the most important element of the relief of the basin is the poliphase valley of the Velika Ukrina, built by the process of the fluvial erosion and denudation (Lazarevic, 2000). The valley of Velika Ukrina emphasize as the most important morphological element, well preserved and expressive, but at the same time important for solving the problem of morphogenesis of the relief of the basin in global. The valley of Velika Ukrina belongs to the type of geological structure, which has by the change of resisting and soft rocks, from well toward mouth of river, provided intensive selective erosion, but also forming of the valley with all its narrows and widenings. From the place of rising of the river flow all the way towards monastery Liplje, Velika Ukrina river has built on the trias - jure basis, which is being interlaced with the row of saging lines and fissures, the cliff valley. At the same time she is the natural boundary among mountain pulse of Uzlomac, which is rising on its left valley side and fluvial surface, which extends toward north on its right valley side. From monastery Liplje up to the conjunction of Bistrica and Lukavac, the valley of Velika Ukrina has been remarkably stretched, which is undoubtedly eminence of the change of processes, but also eminence of geological basis. This morphological entirety eminence with extended valley sides, which are being flooded with the big quantities of fluvial alluvium, which because of reducted erosion process has assumed fossil character. From the conjunction of Bistrica and Lukavac the valley of Velika Ukrina up to its elbow deviation, was built in the basis of the fragments of Miocene age, which is widely extended on the left valley side in the colonies Srednja i Donja Snjegotina. In the lime-stone parties of upper trias age in the colony Stara Dubrava, Velika Ukrina river has incised cliff valley of $2 \mathrm{~km}$, after which the valley of Velika Ukrina changes its direction of extension and deviates toward east. From the elbow deviation up to the conjunction with Mala Ukrina, Velika Ukrina has built wide river valley, which is at the mouth of the river being eminenced with wide alluvial level. Ramified hydrographic network in this part of the basin has provided the opportunity for entrance of the big quantities of fluvial material in this part of the basin, but the material brought by Velika Ukrina, which is sedimented because of reduced falling, has been sedimented along left and right sides of the valley side.

\section{Fluvial and Karst Relief of the Velika Ukrina Valley}

From the aspects of morphological evolution and genesis of the basin of Velika Ukrina the most important element of the relief in the valley of Velika Ukrina are river terraces. River terraces which are noticed along the valley of Velika Ukrina are not always synchronicall, nor they are present along the entire river flow. The reason has to be found in petrographic charac- 
teristics, tectonic activities, fluctuation of the lower erosion basis, but also in climate changes. In the well part of the Velika Ukrina river there are no caught river terraces. The reason is geological basis as well as cliff valley overgrown with wooded vegetation and expressed erosion process, which is on this rock basis of erodibil rocks, reduced the possibility of preserving of the terrace levels. Terrace levels are caught on the exit from the cliff valley, on the right valley side where the highest terrace level lies on the 390 meters of absolute altitude, and the lower one on 380 meters of absolute altitude. These two terrace levels are fragmentarily saved on the valley sides, which tells us that the relation among vertical and side erosion was changing and that the side movings in the periods of relative stoppage produced creating of terrace levels. On the place of conjunction of Bistrica and Lukavac rivers the highest terrace level has been preserved on the absolute altitude of 340 meters and the lower one on the 240 meters of absolute altitude.The highest terrace level in height correlation of terrace levels could be connected with highest that was caught on the exit from rising part of cliff valley, because he is dominating along entire river flow of Velika Ukrina up to the elbow deviation. Lower terrace level is on this place lower for 100 meters of relative altitude which meets the statute by which river terrace increases its relative and decreases its absolute altitude along the profile of the river. Higher terrace level on 280 meters and lower on 240 meters of absolute altitude was caught also in trias cliff, in Stara Dubrava location, as well as in Jankovici village where the higher terrace level lies on 300 meters of absolute altitude and the lower one on 240 absolute altitude. However, after elbow deviation of river valley of Velika Ukrina lower terrace level which we were following up to the elbow deviation has not been expressive in the morphology of the basin, only terrace level on 240 meters of absolute altitude was noticed, which meets the lower terrace level in the valley before elbow deviation. According to mentioned locations where terrace levels are present in the valley of Velika Ukrina, two terrace levels could be extracted, dominating higher up to elbow deviation of river valley and lower dominating up to the mouth of the river. Beside above mentioned terrace levels as explicit elements of fluvial relief in basin of Velika Ukrina, one fluvial surface has been noticed. Fluvial surface, which is secondary watershed among Bistrica and Lukavac rivers with average altitude of 800 to 600 meters of absolute altitude, mildly falls trough villages Jotanovici, Stojanovici, Dujakovici i Milicevici toward north where it is remarkably fragmented and changed by fluvial - denudation process. Fluvial surface is probably part of one "pineplen" which is by egzogenical processes remarkably changed, meaning fragmented so during the certain period of time has assumed the view of mildly waved hilly - hillocked relief. As special rarity, on this fluvial surface the entire row of monadnok (ostenjaka) are extracted and they rise up from this surface. Because of different erosion and resistance of rocks basis to fluvial - denudation processes, they are left to protrude, and if we connect their absolute altitudes, we can conclude that they belonged to the unique fluvial surface that is during the geological past by fluvial - denudation processes fragmented and remarkably reduced.

Karst relief in basin of Velika Ukrina was noticed in one isolated rock party of upper trias, on the locations on the left and right valley side of Velika Ukrina, respectively in the colony Stara Dubrava, Gornji Vijacani, Kajsko brdo and along the basins of the Kamenice and Loncarice rivers. The shapes of surface lime-stone relief are weakly developed, represented as a couple of funnel-shaped holes in the line-stone formation of plate shape covered with vegetation. Because, erosion activity of water in lime-stone has space characteristic, it is clear that there are conditions for building the different underground shapes, because they are in morphological hidrographic conection with topographic surface of lime-stone. On the right valley side of the Velika Ukrina river the cave has been placed which entrance lies on 290 meters of apsolute altitude, respectively on 90 meters of relative altitude of river flow of Velika Ukrina.

Speleogenesis of this cave object "Vukovi sa vucijaka" is relatively simple, because on the basis of morphological tracks in space environment of this geomorphological object some conclusions could be made, which speak enclosed to understanding of evolution of speleological object (Lazarevic, 1999).
Surface flow on the map marked as periodical flow, represents the direction of swelling of surface waters from valley side and watershed in the direction of river bed of Velika Ukrina.

When came to the lime-stone basis, fluvial process which was directed to destruction of rocks, was replaced with lime-stone process when the fase of building of first lime-stone formes started, attic and partialy wall ornament and compresses on the surfaces out of reach of river water. Cave canal, 12 meters long, filled wtih casts and drapery of different sizes, but also with small examples of started process of forming the stalactites from the attic of the cave, finish in the big hall from which leads the canal up to river bad. Trough cave canal, and partialy trough the hall 19 meters long, and 15 meters wide and 22 meters high, hidrographic relation was held with the river flow of Velika Ukrina. However, when in this rock party the formation for exploatation of lime-stone was placed, this relation was broken, and cave canals and the hall during the time were destroyed. In the next phase of explatation of the lime-stone the hall and the entrance canal will be completely destroyed. Therefore this research is the last try for this geomorphological object to be protected and extracted from oblivion.

\section{Morphogenesis of the Relief of the Basin of Velika Ukrina}

In morphochronological sense the basic question is the time of formation, respectively the age of the Velika Ukrina river as well as the lements of its relief. Beginning of the flow and the development of the along profile of Velika Ukrina is conected to retreatment of pliocen lake, which was the lower abrasio basis for the rivers of Savski basin. The lake phase kept untill the middle of pleistocen, after which fluvial period came up and in the lower parts of Pannonian basin. Hidrographic system of tributaries of the Sava have had the similar development, if valleys weren't flooded bz Panonical sea, but also if the most of tributaries and their partial parts, were not under the water of smaller isolated terciar basins (Dukic, 1957). Lake phase in the basin of Velika Ukrina was marked by terciar basins of its environment, on the first place basin of Teslic and kotor varos, which were most likely comunicated in the period when 
the maximal level was crossing over 780 meters of apsolute altitude. However, in the period of succesion of lake level,in the period of lower and middle miocen, original sea gulfs, which were conected loose their conection and form the shallowly isolated lake environments. This type of environments have been noticed in the basin of Velika Ukrina, respectively those basins are: Snjegotina, Torina and Krsila. On the basis of the facts one could conclude that the river system of Velika Ukrina (well and the higher part of the flow) was relatively distant from the lower abrasio basis of Panonical sea. River flow of Velika Ukrina has become, after retreating the marine - lake conditions from this part. Morphological tracks of abrasio relief in the basin of Velika Ukrina are not present because they were destroyed by intensive fluvial erosion and denudation in the long geological period, but if taken into consideration that the higher boundary of lake level in Teslic neogen basin (to this epigenies direct) was up to 780 meters, and that the higher from noticed levels of neogen sediments (450 meters of apsolute altitude) in the basin of Velika Ukrina, there is real opportunity that the morphological tracks of abrasio shapes were present (Crnogorac, 2000). The oldest and the highest element of the relief in the basin of Velika Ukrina is fluvial surface which has apsolute height of 800 meters in beneath of Borje mountain, while downriver toward north this height falls up to 400 meters. In the fluvial surface which is crossed with tectonic fissures started to verticaly incise Velika Ukrina forming cliff valley in well part. Incising of the cliff of Velika Ukrina (Bistrica) started from terrase level 300 meters of apsolute altitude, which is dominating along the profile up to elbow deviation. This terrase level is the witness of one phase in which the profile of Velika Ukrina was agreed, however non presence of higher terrase level from 300 meters of apsolute altitude in the part of the basin after elbow deviation, is the proof that the lower erosion basis for Velika Ukrina in this phase of forming the profile couldn't be the Ukrina river.

This fact forced the need that beside noticed tracks of fossil river valley northern from elbow deviation, to search for higher terrase level, because he had to be falling toward some lower erosion basis. On the basis of morphological tracks of fossil valley, which was orientated towards north, higher terrace level from 300 meters of absolute altitude, was noticed in the basin of Turjanica river, which was orientated toward north. Noticed morphological track, higher terrace level, confirms the thesis about northern direction of extending of the river valley of Velika Ukrina in the phase of forming the profile on the absolute altitude of 300 meters.

Beside morphological track toward this thesis are geological proofs, which direct that the material (sandy and kvarc, which shape is the best kept), by which the valley of Velika Ukrina was filled up to elbow deviation, were found in the open profiles in the basin of Turjanica. Sagged line which meets with the flow of Snjegotina river and follows the flow of Velika Ukrina trough trias and forward up to its conjunction with Mala Ukrina, but also the sagging line line od direction Turjanica - Okolica - Kremna - Jelah, of parallel direction, like all other saging on the brim of Panon geosynclinals conditioned during the Pliocene and on the beginning of Pleistocene remarkable changes of initial relief. Beside present saging lines which undoubtly point to tectonicall activity, it is necessary to consider the geomorphological circumstances, because on that way one could make the conclusion if the elbow deviation of river flow and the valley of Velika Ukrina towards east, was caused by younger tectonic movings. With the analyze of the profiles in the level of terrace level of 300meters, before (meridian direction) and after elbow deviation (parallel direction), but in fossil valley, it is noticed that the width of the river valley of Velika Ukrina before elbow deviation in fossil valley 2250 meters, while the width of the valley after elbow deviation in the level of 300 meters is 1000 meters. Analogically to these data one could conclude that the meridian direction of Velika Ukrina in the level of 300 meters was direction by which she was trough the valley of Turjanica connected for lower erosion basis of the Vrbas river in that phase of building of the side profile. After tectonic activity which caused the elbow deviation of the river flow of Velika Ukrina toward east, Velika Ukrina, abandoning its river bad respectively river valley (fossil valley), starts by leaking its right watershed, to make connection with some present river network, which communicated with the flow of Ukrina. Incising of its long profile, starts after tectonic activities which caused significant changes in the initial relief, respectively, in the watershed, which is crossed parallel watershed, Velika Ukrina forms permeability and entrance into the basin of flows which were orientated toward Ukrina river. by forming the permeability and new orientation of the flow of Velika Ukrina starts the new phase of harmonizing of the profile that was noticed as lower terrace level. Consequently, with geomorphologic analyze of terrace levels in the basin of Velika Ukrina, geological - tectonic condition, but also with analyze of the profile the aim was to fortify, trough development of the along profile, the set hypothesis, but also to point out the morphological evolution of the relief of the basin, because Velika Ukrina by incising its valley, acting of vertical and side erosion, but also by influence of other geomorphological processes was building morphosculpture of the basin.

\section{Literature}

Andjelkovic Milodrag: Tektonika Unutrasnjih i Sredisnjih Dinarida Jugoslavije, Monografije 21, Univerzitet u Beogradu, Beograd, 1980.

Crnogorac Cedomir: Sliv Velike Usore - hidrolosko - geomorfoloske karakteristike, Prirodno - matematicki fakultet u Banjoj Luci, Banja Luka, 2000.

Dukic Dusan: Sava - potamoloska studija, Srpska akademija nauka, posebna izdanja knjiga 12, Beograd, 1957.

Lazarevic Radenko: Geomorfologija, Prirodno - matematicki fakultet $\mathrm{u}$ Banjoj Luci, Banja Luka, 2000.

Lazarevic Radenko: Vaganska Pecina, Srpsko geografsko drustvo, Beograd, 1999.

Sofilj Jovan, Marinkovic Radovan, Pamic Jakob i Djordjevic Dragoslav: Geoloski tumac za list Derventa, Geoinzinjering, Sarajevo, 1983. 